\title{
Valuasi Ekonomi Taman Purbakala Batu Pake Gojeng Melalui Pendekatan Travel Cost Method Jurnal Ecces
}

\author{
Trismawati $^{1}$ \\ Abdul wahab ${ }^{2}$ \\ Wahidah Abdullah ${ }^{3}$
}

1,2,3 Program Studi Ilmu Ekonomi

Fakultas Ekonomi dan Bisnis Islam Universitas Islam Negeri Alauddin Makassar

Jl. Yasin Limpo, No. 36 Samata, Gowa Sulawesi Selatan

E-mail : trismawati14@gmail.com ${ }^{1}$, abdulwahab_2104@yahoo.com, wahidah.abdullah@uinalauddin.ac.id ${ }^{3}$

\section{Abstrak: Valuasi Ekonomi Taman Purbakala Batu Pake Gojeng Melalui Pendekatan Travel Cost Method}

\begin{abstract}
Jumlah pengunjung objek wisata Taman Purbakala Batu Pake Gojeng mengalami peningkatan dalam tiga tahun terakhir. Namun, dibalik peningkatan tersebut, tidak diketahui seberapa besar jumlah permintaan dan nilai ekonomi yang didapatkan konsumen atas permintaan konsumen tersebut. Tujuan dari penelitian ini adalah untuk mengetahui apakah biaya perjalanan, pendapatan, umur, tingkat pendidikan, waktu kerja dan pengalaman pengunjung mempengaruhi jumlah permintaan serta mengetahui nilai ekonomi yang diperoleh pengunjung Objek Wisata Taman Purbakala Batu Pake Gojeng dengan menggunakan pendekatan biaya perjalanan (Travel Cost Method). Alat analisis yang digunakan dalam penelitian ini yaitu analisis regresi linear berganda dengan menggunakan pendekatan Ordinary Least Square dan surplus konsumen, untuk menghitung nilai total ekonomi yang ada. Hasil penelitian menunjukkan tiga variabel independen berpengaruh secara signifikan terhadap jumlah permintaan natara lain biaya perjalanan, pendapatan, dan pengalaman berkunjung. Umur, pendidikan dan waktu kerja tidak berpengaruh secara signifikan terhadap jumlah permintaan. Surplus yang dicapai konsumen sebesar Rp 99.503,96 per individu per satu kali kunjungan menunjukkan bahwa keuntungan yang diperoleh konsumen masih jauh diatas harga pengeluaran rata-rata yakni sebesar Rp. $42.713,13$ per satu kali kunjungan. Nilai total ekonomi, diperoleh dari nilai surplus konsumen per individu per tahun dikalikan dengan jumlah pengunjung tahun 2017. Hasilnya, diperoleh nilai total ekonomi Objek Wisata Taman Purbakala Batu Pake Gojeng sebesar Rp. 1.950.022.176. Dengan demikian, objek wisata ini memiliki prospek yang sangat besar, dan penting didorong pemerintah sehingga dapat menjadi sumber pertumbuhan baru.
\end{abstract}

Kata Kunci: Permintaan, Nilai Ekonomi, Travel Cost Method. 


\section{Abstract: Economic Valuation of Archaeological Park Pake Gojeng Through the Approach of the Travel Cost Method.}

The number of visitors to the Pake Gojeng Archaeological Park tourist attraction has increased in the last three years. However, behind this increase, it is not known how much demand and economic value consumers get at of the customer's demand. The purpose of this study was to find out whether travel costs, income, age, education level, work time and visitor experience influence the number of demand and know the economic value obtained by visitors to Pake Gojeng Stone Archaeological Park using the Travel Cost Method. The analytical tool used in this study is multiple linear regression analysis using the Ordinary Least Square approach and consumer surplus, to calculate the total economic value that exists. The results of the study show that the three independent variables significantly influence the number of requests, including travel costs, income, and visiting experience. Age, education and work time do not significantly influence the number of demand. The consumer's surplus of Rp 99,503.96 per individual per one visit shows that the benefits obtained by consumers are still far above the average expenditure price of Rp. 42,713,13 per one visit. The total economic value, obtained from the consumer surplus value per individual per year multiplied by the number of visitors in 2017. The result, obtained the total economic value of Pake Gojeng Stone Archaeological Park Tourism Object of Rp. $1,950,022,176$. Thus, the tourism attraction has a very large prospect, and is important to be pushed by the government so that it can be a source of new growth.

Keywords: Demand, Economic Value, Travel Cost Method.

\section{PENDAHULUAN / INTRODUCTION}

Jumlah pengunjung objek wisata Taman Purbakala Batu Pake Gojeng mengalami peningkatan dalam tiga tahun terakhir. Namun, dibalik peningkatan tersebut, tidak diketahui seberapa besar jumlah permintaan dan nilai ekonomi yang didapatkan konsumen atas permintaan konsumen tersebut. Informasi tersebut begitu penting, untuk melakukan pengembangan destinasi wisata yang lebih berkualitas dan kompetitif kedepan. Keberadaaan destinasi pariwisata disuatu daerah, akan mengkontribusi pemasukan bagi pemerintah. Pariwisata juga merupakan komoditas yang dibutuhkan oleh setiap individu. Alasannya, karena aktivitas berwisata bagi seorang individu dapat meningkatkan daya kreatif, menghilangkan kejenuhan kerja relaksasi, berbelanja, bisnis, mengetahui peningkatan sejarah dan budaya suatu entnik tertentu, kesehatan dan pariwisata spiritualisme. Dengan meningkatnya waktu luang sebagai akibat lebih singkatnya hari kerja dan didukung oleh meningkatnya penghasilan maka aktivitas kepariwisataan akan semakin meningkat. 
Tempat rekreasi tidak memiliki nilai pasar yang pasti, maka penilaian atas tempat rekreasi, biasanya dilakukan dengan pendekatan biaya perjalanan (Travel Cost Method). Pendekatan ini menggunakan biaya transportasi atau biaya perjalanan terutama untuk menilai lingkungan pada objek-objek wisata. Pendekatan ini menganggap bahwa biaya perjalanan, serta waktu yang dikorbankan para wisatawan untuk menuju objek wisata tertentu, dianggap sebagai nilai lingkungan yang wisatawan yang siap mereka korbankan untuk mendapatkan kepuasan atas hal itu. Pendekatan biaya perjalanan digunakan untuk menilai manfaat yang diterima masyarakat, dari penggunaan barang dan jasa lingkungan. Pendekatan ini juga mencerminkan kesediaan masyarakat untuk membayar barang dan jasa, yang diberikan lingkungan dibanding dengan jasa lingkungan dimana mereka berada pada saat tersebut. Pendekatan ini telah banyak dipakai dalam perkiraan nilai suatu taman rekreasi, dengan menggunakan berbagai variabel. Pertama kali dikumpulkan data mengenai jumlah pengunjung taman, biaya perjalanan yang dikeluarkan, serta faktor-faktor seperti tingkat pendapatan, tingkat pendidikan, dan mungkin juga agama dan kebudayaan serta kelompok etnik dan sebagainya.

Setiap daerah di Indonesia saling berusaha menunjukkan keunggulan potensipotensi wisata yang dimilikinya, untuk menarik wisatawan untuk berkunjung ke daerah tersebut. Salah satu daerah di Indonesia yang berusaha menunjukkan keunggulan potensi wisatanya adalah Kabupaten Sinjai. Berdasarkan rencana pengembangan pariwisata daerah Kabupaten Sinjai, objek wisata dikategorikan menjadi empat kategori. Objek wisata budaya dan sejarah, yang merupakan objek wisata terbanyak yang akan dikembangkan yaitu sebesar 61 persen dari total objek wisata. Selanjutnya objek wisata terbanyak kedua yang dikembangkan yaitu objek wisata alam dan buatan sebesar 18 persen. Kemudian objek wisata ketiga terbanyak, yaitu objek wisata bahari sebesar 14 persen dan diikuti objek wisata minat khusus sebesar 7 persen. Kabupaten Sinjai setiap tahunnya dipenuhi berbagai wisatawan, baik wisatawan nusantara maupun wisatawan mancanegara. Pemerintah dalam tugasnya sebagai pengatur administrasi daerah, semakin sering mengadakan berbagai kegiatan, baik itu tingkat nasional maupun internasional. Terbukti dari data statistik yang ada, wisatawan yang berkunjung ke Kabupaten Sinjai semakin meningkat setiap tahunnya. Jumlah pengunjung wisatawan nusantara dari tahun 2014 sampai tahun 2017 selalu 
mengalami peningkatan. Sementara jumlah pengunjung wisatawan mancanegara mengalami penurunan dari tahun 2014 sampai dengan tahun 2016, hingga pada pada tahun 2017 kembali mengalami peningkatan. Akan tetapi, secara keseluruhan jumlah pengunjung wisatawan objek wisata Kabupaten Sinjai, terus mengalami peningkatan dari tahun 2014 sampai tahun 2017.

Salah satu objek wisata yang telah cukup lama dikembangkan di Kabupaten Sinjai adalah Objek Wisata Taman Purbakala Batu Pake Gojeng Kabupaten Sinjai. Objek wisata budaya dan sejarah ini secara geomorfologi terletak di ketinggian sekitar 59 s.d 96 meter di atas permukaan laut. Diatas bukit tersebut terdapat situs Batu Pake Gojeng yang merupakan kuburan batu. Puncak Taman Purbakala Batu Pake Gojeng ini merupakan benteng pengintaian dan markas pertahanan Jepang di masa lalu yang memungkinkan mereka dengan mudah mengawasi kapal laut yang melintasi Teluk Bone, maupun pesawat terbang sekutu. Dari puncak bukit dapat dilihat panorama alam Kota Sinjai dengan deretan pulau Sembilan, serta jejeran rimbunan hutan bakau Tongke-Tongke. Objek Wisata Taman Purbakala Batu Pake Gojeng memanfaatkan sumber daya alam dan lingkungan sebagai modal utamanya, yang merupakan barang publik yang tidak memiliki harga pasar, sehingga diperlukan suatu metode valuasi jasa lingkungan untuk menentukan harga pasarnya.

\section{TINJAUAN TEORITIK / LITERATURE REVIEW}

\section{Permintaan}

Mankiw (2007) mengemukakan permintaan didasarkan atas tingkat kepuasan dalam mengonsumsi barang dan pendapatan yang dibelanjakan, dimana konsumen berusaha memaksimunkan kepuasaan dengan keterbatasan/kendala pendapatan. Permintaan adalah keinginan yang disertai dengan kesediaan serta kemampuan untuk membeli barang yang bersangkutan. Permintaan ada 2 yaitu permintaan individu dan permintaan pasar. Permintaan individu adalah permintaan sejumlah barang oleh konsumen pada berbagai tingkat harga barang. Sedangkan permintaan pasar adalah penjumlahan dari permintaanpermintaan individual membentuk permintaan pasar. Faktor-faktor yang mempengaruhi permintaan ada beberapa hal, antara lain; 1). Harga Barang Tersebut. Harga suatu barang mempengaruhi jumlah barang yang diminta (dibeli). Hubungan antara harga dan permintaan barang itu adalah berbanding terbalik. Semakin murah harga maka jumlah barang yang diminta akan semakin banyak. 2). Harga Barang Substitusi. Barang substitusi 
adalah barang lain atau pengganti yang jenis atau tujuannya adalah sama. Jadi apabila terjadi kenaikan harga barang substitusi maka mengakibatkan kenaikan pada permintaan atas barang itu. 3). Pendapatan. Bila pendapatan seseorang meningkat, berarti orang itu memiliki kemampuan yang lebih besar untuk membeli barang, yang akhirnya menyebabkan permintaan akan barang menjadi meningkat. 4). Ekspektasi harga di masa yang akan datang. Bila semua masyarakat beranggapan bahwa di masa yang akan datang akan terjadi kenaikan harga pada suatu barang, maka permintaan akan barang tersebut akan semakin meningkat. 5). Jumlah konsumen. Apabila jumlah konsumen atau pembeli betambah, maka semakin banyak permintaan akan barang tersebut. 6. Selera (trend). Bila suatu barang menjadi mode atau trend di kalangnan masyarakat, maka permintaan atas barang tersebut meningkat dengan pesat.

Namun sedikit berbeda dengan pandangan Nicholson, (1995) yang mencoba mengungkapkan bahwa permintaan permintaan dapat dibedakan atas permintaan efektif dan permintaan absolut. Daya beli konsumen disebut dengan permintaan efektif. Jika permintaan hanya didasarkan atas kebutuhan saja dikatakan sebagai permintaan absolut. Kemampuan membeli seseorang tergantung atas dua unsur pokok yaitu, pendapatan yang dibelanjakan dan harga barang yang dikehendaki. Apabila jumlah pendapatan yang dapat dibelanjakan oleh seseorang berubah, maka jumlah barang yang diminta juga akan berubah. Demikian juga halnya apabila harga barang yang dikehendaki berubah maka jumlah barang yang dibeli juga akan berubah.

\section{Valuasi Ekonomi}

Menurut Clawson dalam Perman (1996), secara umum dapat didefinisikan bahwa valuasi ekonomi pada dasarnya adalah suatu upaya untuk memberilkan nilai kuantitatif terhadap barang dan jasa yang dihasilkan oleh sumber daya alam. Metode Travel Cost telah diterapkan secara luas di negara maju, terutama untuk menganalisis permintaan terhadap rekreasi di alam terbuka. Pendekatan ini didasarkan pada konsep sederhana Harold Hotelling (1931) yang menyebutkan kebiasaan yang diamati dapat digunakan untuk membuat kurva permintaan dan menentukan nilai dari sumberdaya alam dan lingkungan. Juga dapat digunakan untuk menghitung surplus konsumen dari sumberdaya alam dan lingkungan yang tidak mempunyai pasar melalui pertanyaan yang difokuskan pada peningkatan biaya perjalanan sebagai pasar pengganti. Semua individu akan memberikan reaksi yang sama 
Trismawati, Wahab, Wahida, Valuasi Ekonomi Taman Purbakala ...

terhadap peningkatan/penurunan biaya perjalanan dan juga terhadap peningkatan/penurunan tarif masuk untuk mengunjungi suatu tempat rekreasi (Perman, et al, 1996).

\section{METODE PENELITIAN / METHODS}

Pada penelitian ini menggunakan metode biaya perjalanan individu (Individual Travel Cost Method), yang biasanya dilaksanakan melalui survey kuesioner pengunjung mengenai biaya perjalanan yang harus dikeluarkan ke lokasi wisata, kunjungan ke lokasi wisata yang lain (substitute sites), dan faktor-faktor sosial ekonomi lainnya.

Untuk menghitung biaya perjalanan dengan menggunakan pendekatan biaya perjalanan individu (Individual Travel Cost Method / ITCM ) dapat dicari dengan menggunakan rumus berikut:

$$
\mathrm{Bpt}=\mathrm{Bt}+\mathrm{Bk}+\mathrm{Bkm}
$$

Keterangan:

$$
\begin{aligned}
& \text { Bpt = Biaya Perjalanan Total } \\
& \text { Bt }=\text { Biaya Transportasi } \\
& \text { Bk = Biaya Konsumsi } \\
& \text { Bkm = Biaya Karcis Masuk. }
\end{aligned}
$$

Dalam penelitian ini untuk menghitung valuasi ekonomi digunakan metode biaya perjalanan individu (Individual Travel Cost Method), yaitu dengan menghitung surplus konsumen tiap individu pertahun.

Untuk menghitung nilai surplus konsumen, menggunakan formulasi sebagai berikut:

$D x=Q x=a-b P$

Persamaan diatas digunakan untuk menghasilkan surplus konsumen sebagai nilai ekonomi. Untuk menghasilkan surplus konsumen per individu per tahun, digunakan perhitungan 
integral terbatas, dengan batas bawah yaitu harga terendah dan batas teratas yaitu harga tertinggi, sehingga dapat diformulasikan sebagai berikut:

$S K=S K=\int_{P_{0}}^{P_{i}} f\left(P_{x}\right) d P$

Dimana:

SK = Surplus Konsumen

Px = Harga

Selain pendekatan travel cost method, juga digunakan pendekatan analisis regresi berganda. Salah satu tujuan analisis regresi adalah untuk mengestimasi suatu hubungan antara variabel-variabel ekonomi. Hubungan tersebut dapat diekspresikan dalam bentuk persamaan yang menghubungkan variabel terikat $Y$ dengan satu atau lebih variabel bebas $\mathrm{X} 1, \mathrm{X} 2, \mathrm{X} 3, \ldots ., \mathrm{Xn}$. Dalam analisis regresi pola hubungan antar variabel diekspresikan dalam sebuah persamaan regresi yang diduga berdasar data sampel. Untuk mengetahui pengaruh variabel bebas terhadap variabel terikat digunakan alat analisis statistik yaitu regresi linear berganda dengan pendekatan OLS (Ordinary Least Squares). OLS (Ordinary Least Squares) merupakan tekhnik estimasi variabel dependen yang melandasi analisis regresi. Dalam penelitian ini untuk menganalisis permintaan ke Objek Wisata Taman Purbakala Batu Pake Gojeng yang dipengaruhi oleh pendapatan, umur, pendidikan, waktu kerja dan pengalaman pengunjung dapat diformulasikan ke dalam fungsi permintaan sebagai berikut:

$Y=f\left(X_{1}, X_{2}, X_{3}, X_{4}, X_{5}, X_{6}\right)$

Y = Permintaan Objek Wisata Taman Purbakala Batu Pake Gojeng (frekuensi)

X1 = Biaya Perjalanan (Rp)

$\mathrm{X} 2$ = Pendapatan $(\mathrm{Rp})$

$\mathrm{X} 3$ = Umur (tahun)

X4 = Tingkat Pendidikan (tahun) 
X5 = Waktu Kerja (Menit)

X6 $=$ Pengalaman Berkunjung (dummy)

\section{HASIL DAN PEMBAHASAN / DISCUSSION}

Variabel-variabel yang telah ditentukan dalam penelitian ini dihitung dengan menggunakan SPSSS 24,00 untuk mengetahui tingkat suatu variabel mempengaruhi jumlah permintaan ke Objek Wisata Taman Purbakala Batu Pake Gojeng. Adapan hasil pengolahannya bisa dilihat dibawah ini:

\section{Uji Multikolinearitas}

Uji multikolineitas bertujuan untuk menguji apakah dalam regresi yang terbentuk ada korelasi yang tinggi atau sempurna diantara variabel bebas atau tidak.

Tabel Hasil Uji Multikolinieritas

\begin{tabular}{lcc}
\hline \multicolumn{1}{c}{ Variable Independen } & Tolerance & VIF \\
\hline Biaya Perjalanan & 0.831 & 1.204 \\
Pendapatan & 0.660 & 1.515 \\
Umur & 0.672 & 1.489 \\
Pendidikan & 0.818 & 1.223 \\
Jam_Kerja & 0.937 & 1.067 \\
Pengalaman Berkunjung & 0.910 & 1.099 \\
\hline
\end{tabular}

Sumber: Hasil Olah Data SPSS 24 (2018).

Hasil regresi dengan menggunakan SPSS 24, maka dari matriks korelasi terlihat bahwa tampilan output VIF dan Tolerance mengindikasikan tidak terdapat multikolineritas. Nilai VIF tidak ada yang melebihi 10 dan nilai Tolerance tidak ada yang kurang dari 0,10.

\section{Uji Heteroskedastisitas}

Untuk menguji ada tidaknya heteroskedastisitas dalam suatu model regresi, maka bisa dilakukan dengan metode analisis grafik dengan mengamati scatterplot. Gambar Scatterplot menunjukkan bahwa titik-titik menyebar secara acak, serta tersebar baik diatas maupun dibawah angka 0 pada sumbu Y. Hal ini dapat disimpulkan bahwa tidak terjadi heteroskedastisitas pada model regresi, sehingga model regresi layak dipakai untuk memprediksi jumlah permintaan Objek Wisata Taman Purbakala Batu Pake Gojeng Kabupaten Sinjai berdasarkan masukan variabel independent biaya perjalanan (travel cost), pendapatan, umur, pendidikan, waktu kerja dan pengalaman berkunjung sebelumnya. 


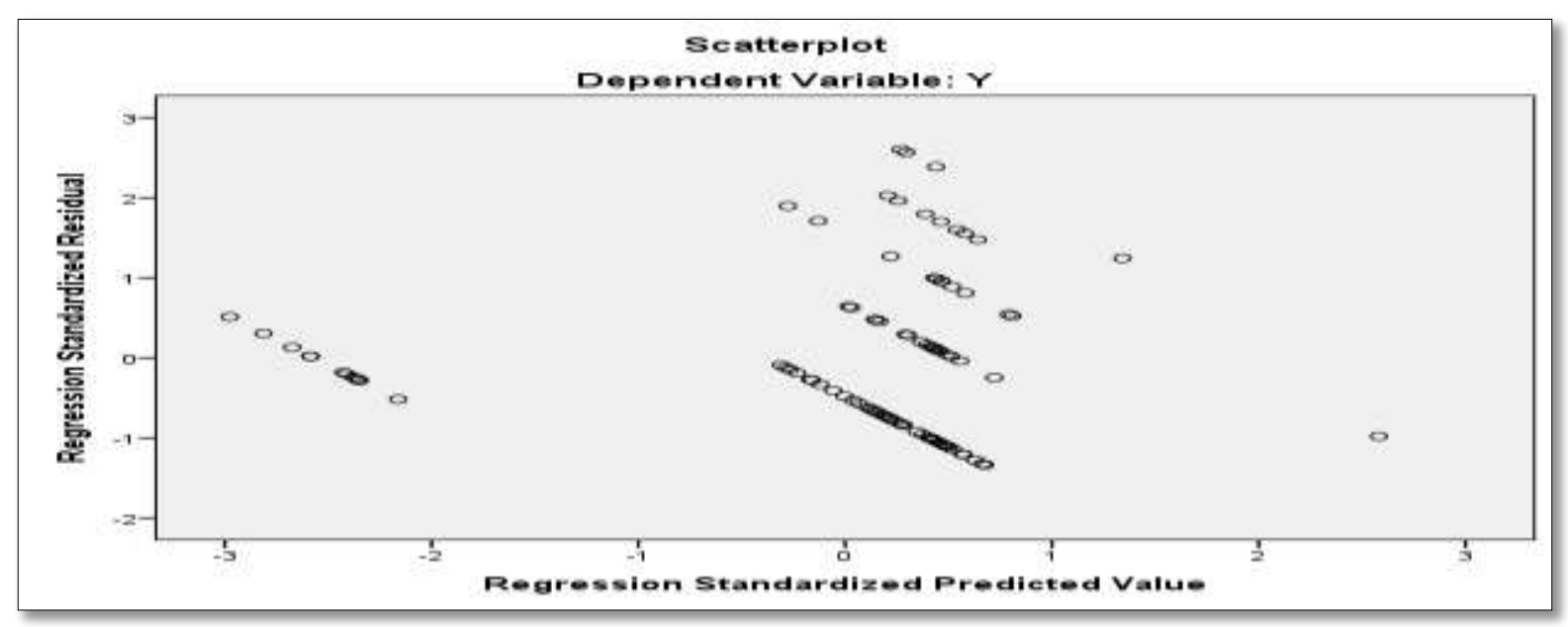

\section{Uji Autokorelasi}

Uji autokorelasi bertujuan untuk menguji apakah dalam model regresi liniear terdapat korelasi, antara kesalahan penggangu pada periode $t$ dengan kesalahan pengganggu pada periode t-1 (sebelumnya). Jika terjadi korelasi, maka dapat dikatakan terdapat problem autokorelasi. Salah satu metode analisis untuk mendeteksi ada tidaknya autokorelasi adalah dengan melakukan pengujian Durbin Watson.

Tabel Durbin-Watson

\begin{tabular}{cc}
\hline Model & Durbin-Watson \\
\hline 1 & 1.632 \\
\hline
\end{tabular}

Sumber: Hasil Olah Data SPSS 24 (2018).

Dari hasil regresi diketahui bahwa nilai Durbin Watson sebesar 1,632. Sedangkan tolak ukur uji autokorelasi adalah Durbin Watson berkisar diatas 1,55 maka dikatakan tidak terjadi autokorelasi, jadi hasil kesimpulan uji statistik Durbin Watson penelitian ini diatas 1,55 maka dikatakan tidak terjadi autokorelasi. Dalam penelitian ini untuk menganalisis permintaan ke Objek Wisata Taman Purbakala Batu Pake Gojeng yang dipengaruhi oleh pendapatan, umur, pendidikan, waktu kerja dan pengalaman pengunjung dapat diformulasikan ke dalam fungsi permintaan sebagai berikut:

$Y=f\left(X_{1}, X_{2}, X_{3}, X_{4}, X_{5}, X_{6}\right)$ 
Analisis Regresi Linear Berganda

\begin{tabular}{|c|c|c|c|c|c|c|}
\hline \multicolumn{7}{|c|}{ Coefficients $^{a}$} \\
\hline \multirow{2}{*}{\multicolumn{2}{|c|}{ Model }} & \multicolumn{2}{|c|}{$\begin{array}{l}\text { Unstandardized } \\
\text { Coefficients }\end{array}$} & \multirow{2}{*}{$\begin{array}{l}\text { Standardized } \\
\text { Coefficients } \\
\text { Beta } \\
\end{array}$} & \multirow[b]{2}{*}{$\mathrm{T}$} & \multirow[b]{2}{*}{ Sig. } \\
\hline & & $\mathrm{B}$ & Std. Error & & & \\
\hline 1 & (Constant) & .303 & .407 & & .745 & .458 \\
\hline & Biaya_Perjalanan & -.002 & .001 & -.198 & -2.849 & .005 \\
\hline & Pendapatan & .000152 & .000 & .184 & 2.357 & .021 \\
\hline & Umur & -.050 & .058 & -.167 & -.862 & .391 \\
\hline & Pendidikan & .008 & .101 & .006 & .084 & .933 \\
\hline & Jam_Kerja & .018 & .020 & .057 & .873 & .385 \\
\hline & $\begin{array}{l}\text { Pengalaman } \\
\text { Berkunjung }\end{array}$ & 1.251 & .110 & .754 & 11.355 & .000 \\
\hline & $\begin{array}{l}\mathrm{R}^{2}=0,631 \\
\text { Adjusted } \mathrm{R}^{2}= \\
0,607 \\
\mathrm{~F}_{\text {hituna }}=26,215 \\
\text { Sig } \mathrm{F}=0,000\end{array}$ & & & & & \\
\hline
\end{tabular}

Sumber: Hasil Olah Data SPSS 24 (2018)

Nilai variabel biaya perjalanan sebesar -0,002 dapat diartikan bahwa apabila biaya perjalanan meningkat sebesar 1 rupiah maka akan mengurangi jumlah permintaan ke Objek Wisata Taman Purbakala Batu Pake Gojeng sebesar 0,002 kali, begitupun sebaliknya. Dengan asumsi bahwa variabel lain tetap. Nilai variabel pendapatan sebesar 0,000152 dapat diartikan bahwa apabila pendapatan meningkat sebesar 1 rupiah, maka akan meningkatakan jumlah permintaan ke Objek Wisata Taman Purbakala Batu Pake Gojeng sebesar 0,000152 kali , begitupun sebaliknya. Dengan asumsi bahwa variabel lain tetap. Nilai variabel umur sebesar -0,050 dapat diartikan bahwa apabila umur meningkat sebesar 1 tahun, maka akan mengurangi jumlah permintaan ke Objek Wisata Taman Purbakala Batu Pake Gojeng sebesar 0,050 kali, begitupun sebaliknya. Dengan asumsi bahwa variabel lain tetap.

Nilai variabel tingkat pendidikan sebesar 0,008 dapat diartikan bahwa apabila tingkat pendidikan meningkat sebesar 1 tahun maka akan meningkatkan jumlah permintaan ke Objek Wisata Taman Purbakala Batu Pake Gojeng sebesar 0,008 kali, begitupun sebaliknya. Dengan asumsi bahwa variabel lain tetap. Nilai variabel waktu kerja sebesar 0,018 dapat diartikan bahwa apabila jam kerja meningkat sebesar 1 jam maka akan meningkatkan jumlah permintaan ke Objek Wisata Taman Purbakala Batu Pake Gojeng sebesar 0,018 kali, begitupun sebaliknya. Dengan asumsi bahwa variabel lain tetap. Nilai variabel pengalaman berkunjung sebelumnya sebesar 1,251 dapat diartikan bahwa apabila pengalaman 
berkunjung meningkat sebesar 1 satuan maka akan meningkatkan jumlah permintaan ke Objek Wisata Taman Purbakala Batu Pake Gojeng sebesar 1,251 kali, begitupun sebaliknya. Dengan asumsi bahwa variabel lain tetap. Nilai konstanta $\beta 0$ sebesar 0,303 dapat diartikan bahwa apabila semua variabel bebas yaitu biaya perjalanan ke Objek Wisata Taman Purbakala Batu Pake Gojeng Kabupaten Sinjai, pendapatan, umur, pendidikan, waktu kerja dan pengalaman berkunjung sebelumnya dianggap sama dengan nol, maka jumlah permintaan bernilai 0,303 kali dalam 1 bulan terakhir.

\section{Pengaruh Biaya Perjalanan Terhadap Permintaan Objek Wisata}

Hipotesis yang menyatakan bahwa biaya perjalanan (trave cost) berpengaruh negatif dan signifikan terhadap jumlah permintaan Objek Wisata Taman Purbakala Batu Pake Gojeng Kabupaten Sinjai diterima atau hipotesis yang pertama terbukti. Variabel biaya perjalanan (travel cost) memiliki pengaruh yang negatif dan signifikan terhadap jumlah permintaan dengan nilai koefisien regresi sebesar $-0,002$ yang berarti kenaikan satu rupiah biaya perjalanan untuk satu kali kunjungan yang dikeluarkan oleh responden menyebabkan penurunan jumlah permintaan ke Objek Wisata Taman Purbakala Batu Pake Gojeng Kabupaten Sinjai sebesar 0,002 per tahun dengan asumsi bahwa pendapatan, umur, pendidikan, jam kerja dan pengalaman berkunjung sebelumnya dalam keadaan tetap (konstan). Dengan demikian semakin tinggi biaya perjalanan ke Objek Wisata Taman Purbakala Batu Pake Gojeng Kabupaten Sinjai maka semakin berkurang jumlah permintaan wisatawan ke Objek Wisata Taman Purbakala Batu Pake Gojeng.

Biaya perjalananan merupakan salah satu faktor yang mempengaruhi jumlah permintaan. Dimana biaya perjalanan menjadi pertimbangan seseorang dalam melakukan wisata. Oleh karena itu, biaya perjalanan dalam penelitian ini berpengaruh negatif dan signifikan terhadap permintaan objek wisata. Hasil penelitian ini sejalan dengan penelitian yang dilakukan oleh Hendro Ekwarso, dkk (2010). Dimana variabel biaya perjalanan berpengaruh negatif dan signifikan terhadap jumlah kunjungan pada Objek Wisata Air Panas Pawan di Kabupaten Rokan Hulu, Riau.

\section{Pengaruh Pendapatan Terhadap Permintaan Objek Wisata}

Hipotesis yang menyatakan bahwa pendapatan berpengaruh positif dan signifikan terhadap jumah permintaan Objek Wisata Taman Purbakala Batu Pake Gojeng Kabupaten Sinjai diterima. Variabel pendapatan memiliki pengaruh yang positif dan signifikan terhadap 
jumlah permintaan dengan nilai koefisien regresi sebesar 0,000152 yang berarti kenaikan pendapatan sebesar satu rupiah akan mengakibatkan kenaikan jumlah permintaan ke Objek Wisata Taman Purbakala Batu Pake Gojeng Kabupaten Sinjai sebesar 0,000152 dengan asumsi bahwa biaya perjalanan, umur, pendidikan, jam kerja dan pengalaman berkunjung sebelumnya dalam keadaan tetap (konstan). Dengan demikian, semakin tinggi pendapatan yang diperoleh responden akan meningkatkan jumlah permintaan ke Objek Wisata Taman Purbakala Batu Pake Gojeng Kabupaten Sinjai.

Pendapatan seseorang akan menentukan, apakah ia dapat melakukan perjalanan wisata atau tidak. Ia akan berwisata jika ia mempunyai uang lebih, yang tidak akan mempengaruhi keadaan rumah tanggangganya kalau ia membelanjakan uang tersebut. Oleh karena itu, semakin tinggi pendapatan sesorang maka semakin besar pula kemungkinan seseorang untuk berwisata. Hal ini sejalan dengan penelitian yang dilakukan oleh Irma Afia Salma dan Indah Susilowati (2004). Berdasarkan penelitian yang mereka lakukan di Curug Sewu didapatkan bahwa variabel pendaptan bernilai positif, yang berarti bahwa semakin tinggi pendapatan seseorang maka semakin tinggi jumlah permintaan ke Objek Wisata Alam Curug Sewu.

\section{Pengaruh Umur terhadap Permintaan Objek Wisata}

Hipotesis yang menyatakan bahwa umur berpengaruh negatif terhadap jumlah permintaan Objek Wisata Taman Purbakala Batu Pake Gojeng di terima. Variabel umur memiliki pengaruh yang negatif tetapi tidak signifikan terhadap jumlah permintaan dengan nilai koefisien regresi sebesar $-0,050$ yang berarti kenaikan umur sebesar satu tahun akan mengakibatkan penurunan jumlah permintaan ke Objek Wisata Taman Purbakala Batu Pake Gojeng Kabupaten Sinjai sebesar -0,050 dengan asumsi bahwa biaya perjalanan, pendapatan, pendidikan, jam kerja dan pengalaman berkunjung sebelumnya dalam keadaan tetap (konstan). Dengan demikian, semakin tinggi umur responden akan menurunkan jumlah permintaan ke Objek Wisata Taman Purbakala Batu Pake Gojeng Kabupaten Sinjai. Hasil penelitian ini sejalan dengan penelitian yang dilakukan oleh Deva Millian Satria Yuwana (2010). Dimana variabel umur tidak berpengaruh secara signifikan terhadap permintaan Kunjungan Objek Wisata Kawasan DataranTinggi Dieng Kabupaten Banjarnegara.

\section{Pengaruh Tingkat Pendidikan Terhadap Permintaan Objek Wisata}

Hipotesis yang menyatakan bahwa tingkat pendidikan berpengaruh positif terhadap jumlah permintaan Objek Wisata Taman Purbakala Batu Pake Gojeng Kabupaten Sinjai di terima. Variabel tingkat pendidikan memiliki pengaruh yang positif tetapi tidak signifikan terhadap jumlah permintaan dengan nilai koefisien regresi sebesar 0,008 yang berarti 
kenaikan tingkat pendidikan sebesar satu tahun akan mengakibatkan peningkatan jumlah permintaan ke Objek Wisata Taman Purbakala Batu Pake Gojeng Kabupaten Sinjai sebesar 0,008 dengan asumsi bahwa biaya perjalanan, pendapatan, umur, jam kerja dan pengalaman berkunjung sebelumnya dalam keadaan tetap (konstan). Dengan demikian, semakin tinggi pendapatan yang diperoleh responden akan meningkatkan jumlah permintaan ke Objek Wisata Taman Purbakala Batu Pake Gojeng Kabupaten Sinjai.

Hal ini tidak sejalan dengan penelitian yang dilakukan oleh Irma Afia Salma dan Indah Susilowati (2004). Berdasarkan penelitian yang mereka lakukan di Curug Sewu variabel tingkat pendidikan bernilai negatif, yang berarti bahwa semakin tinggi pendidikan seseorang maka akan menurunkan jumlah permintaan ke Objek Wisata Alam Curug Sewu. Sedangkan penulis memasukkan variabel tingkat pendidikan dan berpengaruh positif terhadap permintaan Objek Wisata Taman Purbakala Batu Pake Gojeng Kabupaten Sinjai. Sejalan dengan penelitian yang dilakukan oleh Yuzuardi Haban, dkk. Dimana variabel tingkat pendidikan berpengaruh positif terhadap jumlah permintaan Kebun Raya Bogor.

\section{Pengaruh Waktu Kerja Terhadap Permintaan Objek Wisata}

Hipotesis yang menyatakan bahwa waktu kerja berpengaruh negatif dan signifikan terhadap jumlah permintaan Objek Wisata Taman Purbakala Batu Pake Gojeng Kabupaten Sinjai ditolak. Variabel waktu kerja memiliki pengaruh yang positif dan tidaksignifikanterhadap jumlah permintaan dengan nilai koefisien regresi sebesar 0,018 yang berarti kenaikan jam kerja sebesar satu jam akan mengakibatkan kenaikan jumlah permintaan ke Objek Wisata Taman Purbakala Batu Pake Gojeng Kabupaten Sinjai sebesar 0,018 dengan asumsi bahwa biaya perjalanan, pendapatan, umur, pendidikan, waktu kerja dan pengalaman berkunjung sebelumnya dalam keadaan tetap (konstan). Hal ini sejalan dengan penelitian yang dilakukan Diana Igunawati (2010). Berdasarkan penelitian yang ia lakukan variabel waktu kerja juga tidak berpengaruh secara signifikan terhadap Objek Wisata Tirta Waduk Cacaban, Kabupaten Kendal.

\section{Pengaruh Pengalaman Berkunjung terhadap Permintaan Objek Wisata}

Hipotesis yang menyatakan bahwa pengalaman berkunjung sebelumnya berpengaruh positif dan signifikan terhadap jumlah permintaan Objek Wisata Taman Purbakala Batu Pake Gojeng Kabupaten Sinjai. Variabel pengalaman berkunjung sebelumnya memiliki pengaruh yang positif terhadap jumlah permintaan dengan nilai koefisien regresi 
1,251 yang berarti jika terjadi pengalaman berkunjung sebelumnya maka akan mengakibatkan terjadinya peningkatan jumlah permintaan ke Objek Wisata Taman Purbakala Batu Pake Gojeng Kabupaten Sinjai sebesar 1,251 dengan asumsi bahwa biaya perjalanan, umur, pendidikan, jam kerja dan pengalaman berkunjung sebelumnya dalam keadaan tetap (konstan). Dengan demikian, semakin tinggi pengalaman berkunjung sebelumnya maka semakin tinggi jumlah permintaan ke Objek Wisata Taman Purbakala Batu Pake Gojeng Kabupaten Sinjai.

Hal ini sejalan pula dengan penelitian yang dilakukan oleh Diana Igunawati (2010). Berdasarkan penelitian yang ia lakukan variabel pengalaman Berkunjung sebelumnya juga berpengaruh secara positif dan signifikan terhadap Objek Wisata Tirta Waduk Cacaba, Kabupaten Kendal. Dimaba jika mempunyai pengalaman berkunjung sebelumnya maka akan mengakibatkan terjadinya peningkatan jumlah permintaan Objek Wisata Tirta Waduk Cacaban.

\section{Perhitungan Nilai Ekonomi}

Untuk menghitung valuasi ekonomi dalam penelitian ini, digunakan metode biaya perjalanan individu (individual Travel Cost Method), yaitu dengan menghitung nilai surplus konsumen tiap individu pertahun. Selanjutnya persamaan diatas digunakan untuk menghasilkan surplus konsumen sebagai nilai ekonomi. Untuk menjelaskan surplus konsumen per individu per tahun digunakan perhitungan integral terbatas dengan batas atas sebesar Rp. 124.000 (P1) dan batas bawah sebesar Rp. 5.000 (P0). Hasil perhitungan diperoleh surplus konsumen per individu per tahun adalah Rp. 99.006 dimana pengunjung yang datang ke Objek Wisata Taman Purbakala Batu Pake Gojeng rata-rata telah berkunjung 2 kali ke tempat tersebut. Sehingga diketahui bahwa surplus yang dinikmati oleh konsumen karena kemampuannya untuk membayar melebihi permintaan aktualnya dimana nilai aktual tersebut untuk individu sebesar Rp. 42.713,13 dan surplus konsumen per tahun yang diperoleh sebesar Rp. 99.066 per individu per tahun atau Rp. 49.503,96 per individu per satu kali kunjungan.

Surplus konsumen sebesar Rp. 49.503 per individu per satu kali kunjungan menunjukkan bahwa keuntungan yang diperoleh konsumen yaitu pengunjung Objek Wisata Taman Purbakala Batu Pake Gojeng Kabupaten Sinjai masih jauh diatas harga pengeluaran rata-rata sebesar Rp. 42.713,13 per satu kali kunjungan. Hal ini berarti Objek Taman Wisata Taman Purbakala Batu Pake Gojeng memberikan manfaat yang lebih besar dari apa yang ditawarkan terhadap para pengunjung dan juga dari biaya yang harus mereka keluarkan agar dapat menikmati Objek Wisata Taman Purbakala Batu Pake Gojeng. Untuk memperoleh 
nilai total ekonomi, maka nilai surplus konsumen per individu per tahun sebesar Rp. 99.006 dikalikan dengan jumlah pengunjung tahun 2017 yaitu sebesar 19.696 pengunjung. Sehingga, diperoleh nilai total ekonomi Objek Wisata Taman Purbakala Batu Pake Gojeng sebesar Rp. 1.950.022.176.

\section{KESIMPULAN / CONCLUSION}

Berdasarkan penelitian yang telah dilakukan tentang analisis faktor-faktor yang mempengaruhi jumlah permintaan dan nilai ekonomi Objek Wisata Taman Purbakala Batu Pake Gojeng Kabupaten Sinjai maka dapat disimpulkan bahwa variabel bebas yang mempunyai pengaruh signifikan terhadap jumlah permintaan Objek Wisata Taman Purbakala Batu Pake Gojeng Kabupaten Sinjai adalah Biaya Perjalanan ke Objek Wisata Taman Purbaka Batu Pake Gojeng, pendapatan, dan pengalaman Berkunjung sebelumnya. Sedangkan variabel bebas yang tidak berpengaruh tidak signifikan terhadap jumlah permintaan Objek Wisata Taman Purbakala Batu Pake Gojeng Kabupaten Sinjai adalah umur, pendidikan dan waktu kerja. Nilai Surplus Konsumen setahun yang didapat sebesar Rp. 99.066 per individu per tahun atau Rp. 49.053 per individu per satu kali kunjungan. Sedangkan Nilai Ekonomi total Objek Wisata Taman Purbakala Batu Pake Gojeng Kabupaten Sinjai diperoleh sebesar Rp.1.950.022.176.

Saran yang dapat diaplikasikan ke pemerintah serta pengelola objek wisata tersebut antara lain penambahan dan perawatan fasilitas umum. Fasilitas umum penting untuk dijaga dilokasi wisata. Setiap pengunjun selalu menggunakan fasilitas umum untuk keperluan masing-masing. Fasilitas umum seperti tempat ibadah, wc, kebersihan tempat untuk bersantai dan lainnya yang sangat penting untuk diadakan dan dirawat keberadaannya. Pengelola memiliki peran penting dalam memperhatikan fasilitas ini demi menjaga kenyamanan wisatawan. Meningkatkan keamanan disekitar lokasi wisata, untuk keselamatan dan keamanan wisatawan yang berkunjung untuk menekan angka kriminalitas yang terjadi pada wisatawan. 


\section{DAFTAR PUSTAKA / REFERENCES}

Ekwarso, Hendro. Aqualdo, Nobel dan Sutrisno. 2010.Nilai Ekonomi Lingkungan dan FaktorFaktor yang Mempengaruhi Permintaan Objek Wisata Air Panas Pawan di Kabupaten Rokan Hulu: Pendekatan Biaya Perjalanan. Jurnal Ekonomi. Riau.

Igunawati, Diana. 2010. Analisis Permintaan Objek Wisata Tirta Waduk Cacaban Kabupaten Tegal", Skripsi Semarang: Fakultas Ekonomi Universitas Diponegoro.

Mankiw, G. 2007. Makroekonomi. Edisi keenam. Jakarta: Erlangga

Nicholson, W, 1995. Mikroekonomi Intermediate dan Aplikasinya. Terjemahan dari Intermediate Microeconomics. oleh Agus Maulana. Bina Rupa Aksara. Jakarta.

Perman, R., Yue Ma, and J. McGilvray .1996. Natural Resourses and Environmental Economics, Longman, Singapore.

Salma, Irma Afia dan Susilowati, Indah. 2004.Analisis Permintaan Objek Wisata Alam Curug Sewu Kabupaten Kendal dengan Pendekatan Travel Cost, Jurnal Ekonomi. Kendal. 